\title{
REVIEW
}

\section{Atypical mole syndrome and dysplastic nevi: identification of populations at risk for developing melanoma - review article}

\author{
Juliana Hypólito Silva,' Bianca Costa Soares de Sá," Alexandre Leon Ribeiro de Ávila," Gilles Landman,"' \\ João Pedreira Duprat Neto" \\ 'Oncology School Celestino Bourroul - Hospital AC Camargo, São Paulo, SP, Brazil. "Skin Oncology Department - Hospital AC Camargo - São Paulo, SP, \\ Brazil. "'I Pathology Department - Hospital AC Camargo - São Paulo, SP, Brazil.
}

Atypical Mole Syndrome is the most important phenotypic risk factor for developing cutaneous melanoma, a malignancy that accounts for about $80 \%$ of deaths from skin cancer. Because the diagnosis of melanoma at an early stage is of great prognostic relevance, the identification of Atypical Mole Syndrome carriers is essential, as well as the creation of recommended preventative measures that must be taken by these patients.

KEYWORDS: Dysplastic Nevus Syndrome; dysplastic nevi; melanoma; early diagnosis; Risk Factors.

Silva JH, de Sá BC, Avila ALR, Landman G, Duprat Neto JP. Atypical mole syndrome and dysplastic nevi: identification of populations at risk for developing melanoma - review article. Clinics. 2011;66(3):493-499.

Received for publication on November 23, 2010; First review completed on November 24, 2010; Accepted for publication on November 24, 2010

E-mail: bianca.sa@terra.com.br

Tel.: 5511 2189-5135

\section{INTRODUCTION}

The incidence of cutaneous melanoma has increased rapidly worldwide. ${ }^{1-5}$ Although it corresponds to only $4 \%$ of all skin cancers, it accounts for $80 \%$ of skin cancer deaths. ${ }^{4}$ Because early detection of the disease is implicit in its cure and only $14 \%$ of patients with metastatic disease survive beyond 5 years, ${ }^{4-6}$ knowledge of factors that increase an individual's risk for developing melanoma and diagnosis at an early stage of the disease have great prognostic relevance.

The risk factors for developing melanoma are both genetic and environmental, especially the presence of multiple melanocytic nevi, dysplastic nevi and atypical mole syndrome (AMS), as the main clinical phenotypic susceptibility. $^{4-9}$

In 1820, Norris ${ }^{10}$ described what is currently considered in a family predisposed to melanoma. In 1978, Clark ${ }^{11}$ reported an increased incidence of cutaneous melanoma in families with multiple melanocytic lesions, introducing the melanoma tumor progression model from melanocytic nevi. ${ }^{11,12}$ At the time, Clark used the term $B-K$ mole syndrome using the initials of the patients surnames. ${ }^{11}$ Currently, the terms AMS, Dysplastic Nevus Syndrome and Familial Atypical Multiple-Mole Melanoma Syndrome (FAMMM) have been employed. ${ }^{12}$ In 1985, Elder ${ }^{13}$ extended the theory of "nevus-melanoma" for sporadic dysplastic nevi as a possible precursor to sporadic melanoma.

Copyright (c) 2011 CLINICS - This is an Open Access article distributed under the terms of the Creative Commons Attribution Non-Commercial License (http:// creativecommons.org/licenses/by-nc/3.0/) which permits unrestricted noncommercial use, distribution, and reproduction in any medium, provided the original work is properly cited.
Several studies have shown that the presence of dysplastic nevi considerably increases the risk of developing melanoma, which demonstrates that these lesions, aside from being precursors to disease are also important risk markers. ${ }^{4,7,14-19}$ Nevertheless, the risk magnitude varies among patients with this type of pigmented lesion. $3,4,15,16,20$ There are still controversies in the literature regarding the nomenclature, clinical definition, dermoscopic characteristics and histopathological, genetic and molecular patterns of dysplastic nevi. ${ }^{4,8}$

In this literature review of dysplastic nevi and AMS, we demonstrate the importance of a complete dermatological examination for the evaluation and monitoring of patients with dysplastic nevi and AMS and suggest criteria for follow-up.

\section{Epidemiology}

Dysplastic nevi are relatively common in the general population. ${ }^{8}$ Reports have described the prevalence ranging from $2 \%$ to $53 \%$ in different studies, depending on the diagnostic criteria (clinical or histological). ${ }^{8}$ A more accurate estimate is considered to be about $2 \%-8 \%$ of Caucasians, with a predilection for young individuals (less than 30 to 40 years of age). ${ }^{18}$ The frequency of dysplastic nevi in patients with a history of melanoma is much higher: $34 \%$ to $59 \%{ }^{18}$ Evidence suggests that sun exposure, in addition to genetic susceptibility, may increase the appearance of such nevi. ${ }^{1,8,18}$

Data concerning the prevalence of AMS are difficult to document in part due to the large variability in the diagnostic criteria employed by different studies. Based on estimates by the National Institutes of Health (NIH), it has been estimated that about 32,000 individuals were carriers 
of AMS and familial melanoma in the United States in 1985, while about 4 million had sporadic AMS.,21

\section{Genetics}

AMS can be sporadic or hereditary, in which case autosomal dominant inheritance is suggested with variable expressivity and incomplete penetrance. ${ }^{22}$ To date, no susceptibility gene has been identified for this syndrome. ${ }^{22}$ However, there are reports of associations between development of AMS and changes in chromosomes 9p21 and $1 p 36 .{ }^{23}$ It was demonstrated that the presence of dysplastic nevi increases the risk of melanoma in patients with germline mutations in $C D K N 2 A$, the main genomic locus of melanoma susceptibility. ${ }^{24,25}$ This genomic locus harbors two important genes involved in cell cycle control, senescence and apoptosis: $p 16$ and $p 14 A R F$. The presence of a susceptibility gene for the development of dysplastic nevi was also observed on chromosome $7 q 21.3$ in patients with the $p 16$ gene mutation in four families with familial melanoma. ${ }^{20}$

A high incidence of somatic mutations of the $B R A F$ gene has also been detected in patients with dysplastic nevi and primary melanomas. ${ }^{8}$ Moreover, melanocytic lesions of rapid growth or development are more likely to have mutations in this gene when compared to lesions without a history of changes in their clinical aspects. ${ }^{8}$

Other genetic changes described in dysplastic nevi include microsatellite instability, loss of heterozygosity $(\mathrm{LOH})$ and increased activity of the telomerase enzyme. ${ }^{12}$

Currently, it is known that only $20 \%$ to $30 \%$ of melanomas arise in association with a melanocytic nevus, which indicates that the Clark's theory of progression can explain only one of the paths from carcinogenesis to melanoma. ${ }^{26}$

Patients with dysplastic nevi may have a reduced ability to repair UV-induced DNA damage. ${ }^{8}$

Although genetic and environmental interactions are clearly involved in the melanocytic transformation pathogenesis, the understanding of its molecular mechanisms still remains incomplete. ${ }^{8}$

\section{Clinical Diagnosis}

Clinically, a dysplastic nevus is most often a spotted lesion of $5 \mathrm{~mm}$ or more in diameter, with irregular and poorly defined borders and variable shades of brown, and it may present a reddish hue, with bleaching accomplished using vitropressure. ${ }^{18}$ It often presents a central papule, surrounded by a pigmented macular ring, giving the appearance of a "fried egg". ${ }^{18}$ Thus, there is considerable overlap with the ABCDE rule used for clinical diagnosis of melanoma, namely, A: asymmetry, B: irregular borders C: varied colors, D: diameter $>6 \mathrm{~mm}$ and E: elevation (simultaneous presentation of macular and papular components) (Figure 1). 3,12,18

Dysplastic nevi may be present in any topography, including double-covered areas (such as buttocks and breasts), iris, instep and scalp. ${ }^{1,3,18,27}$ However, despite their occurrence in these unusual areas, the torso is the most common site for dysplastic nevi to develop. ${ }^{18,27}$ These lesions usually occur in puberty but can present in prepubescent children and in adults, and they may remain relatively dynamic in adulthood or disappear. ${ }^{3,18,27}$ It is also observed that the number of dysplastic nevi correlates directly with the total count of melanocytic nevi of the individual. ${ }^{27}$ Furthermore, from a clinical standpoint, it is
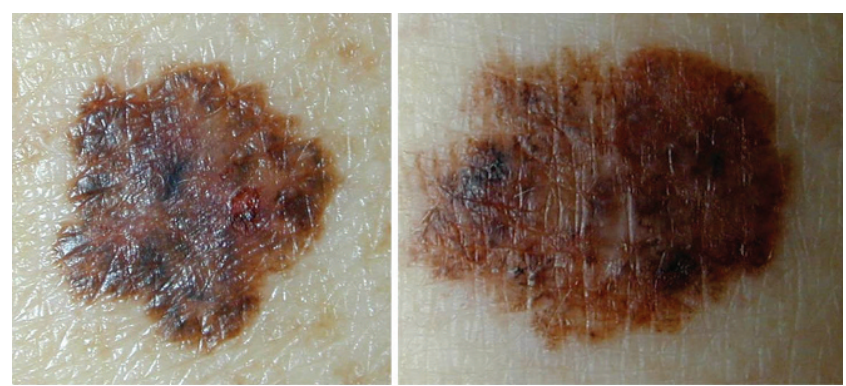

Figure 1 - Macroscopic image of two melanocytic lesions whose characteristics are superimposed by the $A B C D$ rule (asymmetry, irregular borders, varied coloration, diameter greater than $6 \mathrm{~mm}$ ): Left - dysplastic nevus; Right - cutaneous melanoma.

known that the atypical nevus can evolve from a seemingly common melanocytic nevus or show atypical features from its first emergence. ${ }^{27}$ As dynamic lesions, they may become progressively more or less atypical in their clinical aspect. ${ }^{27}$ Although the majority of dysplastic nevi remain stable, regress over time or evolve benignly, monitoring of these lesions is essential. Their prophylactic excision is not justified. $^{8,27}$

AMS has already been described by several authors and institutions based on clinical characteristics of patients and their personal and/or family history of melanoma, with or without histopathological confirmation of an atypical nevus. ${ }^{3}$

According to Newton et al. ${ }^{1}$, AMS can be defined through a scoring system, assigning one point for each feature, as seen in Table 1. Patients with scores greater than or equal to

Table 1 - AMS classifications and their specific characteristics.

\begin{tabular}{|c|c|c|}
\hline CLASSIFICATION & CHARACTERISTICS & COMMENTS \\
\hline $\begin{array}{l}\text { Newton et al. } \\
\text { (1993) }\end{array}$ & $\begin{array}{l}\text { 1) two or more clinically atypical } \\
\text { nevi, 2) more than } 100 \text { nevi in } \\
\text { patients between } 20 \text { and } 50 \text { years } \\
\text { of age, 3) more than } 50 \text { nevi in } \\
\text { patients under } 20 \text { years of age or } \\
\text { more than } 50 \text { years of age, 4) } \\
\text { more than one nevus in buttocks } \\
\text { or instep, 5) nevi on the anterior } \\
\text { scalp, 6) one or more pigmented } \\
\text { lesions in the iris. }\end{array}$ & $\begin{array}{l}\text { Scores greater } \\
\text { than or equal } \\
\text { to } 3 \\
\text { characterize } \\
\text { the AMS } \\
\text { phenotype. }\end{array}$ \\
\hline Classical (1990) & $\begin{array}{l}\text { 1) } 100 \text { or more melanocytic nevi, } \\
\text { 2) one or more melanocytic } \\
\text { nevi greater than or equal to } \\
8 \mathrm{~mm} \text { in its largest diameter, } \\
\text { and 3) one or more clinically } \\
\text { atypical melanocytic nevi }\end{array}$ & $\begin{array}{l}\text { Requires all } \\
\text { features for } \\
\text { diagnosis. High } \\
\text { demand for } \\
\text { total count of } \\
\text { nevi for } \\
\text { classification; } \\
\text { low sensitivity }\end{array}$ \\
\hline $\begin{array}{l}\text { National } \\
\text { Institutes of } \\
\text { Health (NIH) - } \\
\text { Consensus } \\
1992\end{array}$ & $\begin{array}{l}\text { 1) occurrence of melanoma in one } \\
\text { or more first or second degree } \\
\text { relatives, 2) a large number of } \\
\text { melanocytic nevi, often greater } \\
\text { than } 50 \text {, some being atypical and } \\
\text { often variable in size, and } 3 \text { ) } \\
\text { melanocytic nevi that present } \\
\text { certain histological features * } \\
\text { (*defined by Consensus) }\end{array}$ & $\begin{array}{l}\text { Requires } \\
\text { histological } \\
\text { specific } \\
\text { features, still } \\
\text { controversial } \\
\text { and considers } \\
\text { only patients } \\
\text { with family } \\
\text { histories of } \\
\text { melanoma }\end{array}$ \\
\hline
\end{tabular}

Adapted from Newton et al.1993 ${ }^{1}$, Slade et al.1995 ${ }^{3}$ 

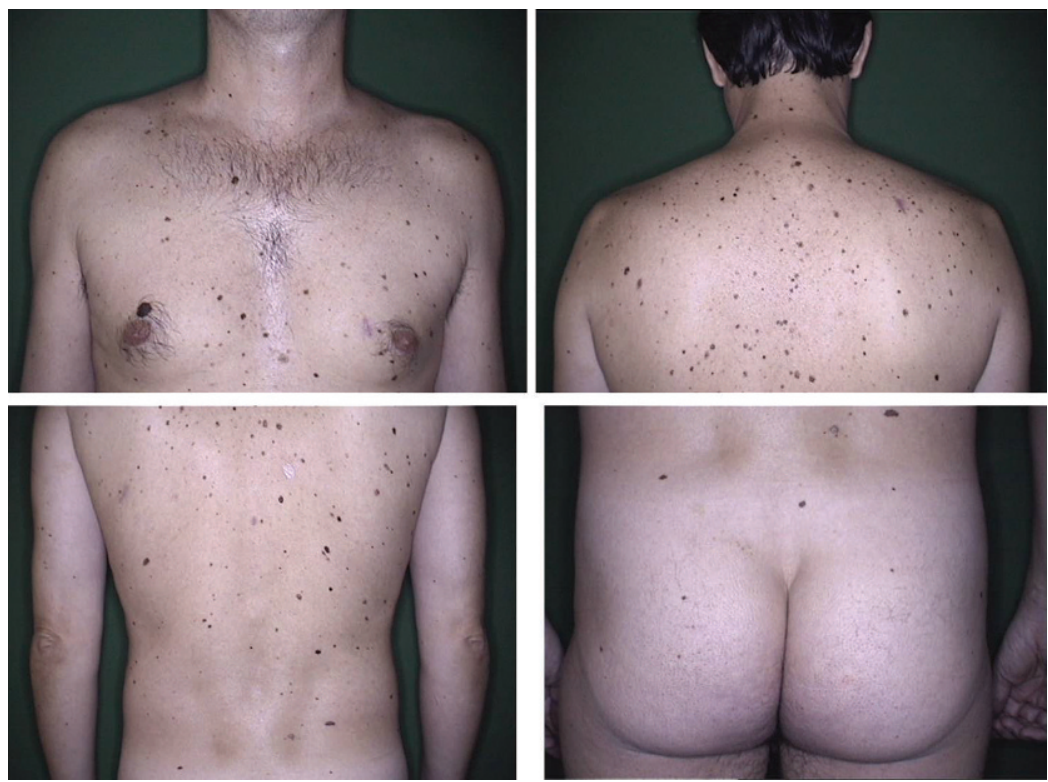

Figure 2 - Body mapping of a male patient, 34 years of age, 256 nevi selected for follow-up. Presents 3 criteria for AMS: more than 100 nevi, presence of more than 2 clinically dysplastic nevi and nevi on the buttocks.

three are considered carriers of AMS phenotype ${ }^{1}$ (Figure 2). Other classifications have also been described, including the so-called Classical AMS which includes patients with over 100 nevi, at least one lesion with clinical features of an atypical nevus and one nevus $8 \mathrm{~mm}$ or more in its largest diameter. ${ }^{3,28}$ The classification devised by the National Institutes of Health (NIH) includes only those patients with a familial history of melanoma (Table 1). ${ }^{29}$

The Kraemer ${ }^{16}$ and Rigel ${ }^{15}$ classifications indicate the magnitude of the risk of melanoma for patients with AMS, which appears to be most dependent on a personal and / or family history of melanoma and for some cases a relative risk (RR) of 1269 has been reported ${ }^{3}$ (Figure 3). According to Kraemer et al. ${ }^{16}$, AMS patients can be classified into the following types according to their heredity characteristics: type A: sporadic AMS; type B: familial AMS; type C: sporadic AMS with personal history of melanoma; type D1: familial AMS, with one family member with a history of melanoma; type D2: familial AMS with two or more family members with a history of melanoma. The different disease types indicate various risks of developing cutaneous melanoma.

Rigel et al. ${ }^{15,30}$ classified AMS patients into four risk groups according to the presence or absence of a personal

\begin{tabular}{|c|c|c|c|c|c|c|c|}
\hline \multicolumn{5}{|c|}{ Kraemer's classification } & \multicolumn{3}{|c|}{ Rigel's classification } \\
\hline \multirow[t]{2}{*}{$\begin{array}{l}\text { Typ } \\
\text { e }\end{array}$} & \multirow[t]{2}{*}{$\begin{array}{l}\text { AN } \\
\text { patient }\end{array}$} & \multirow[t]{2}{*}{$\begin{array}{l}\text { CM } \\
\text { patient }\end{array}$} & \multirow[t]{2}{*}{$\begin{array}{l}\text { AN } \\
\text { Familial }\end{array}$} & \multirow[t]{2}{*}{$\begin{array}{l}\text { CM } \\
\text { Familial }\end{array}$} & $\begin{array}{l}\text { GROU } \\
\mathbf{P}\end{array}$ & SCORE & MM Risk * \\
\hline & & & & & 0 & 0 & $6 \%$ \\
\hline A & + & - & - & - & I & 1 & $10 \%$ \\
\hline B & + & - & + & - & II & 2 & $15 \%$ \\
\hline C & + & + & - & - & III & $3+$ & $50 \%$ \\
\hline \multirow[t]{3}{*}{ D1 } & + & + & + & - & \multirow{4}{*}{\multicolumn{3}{|c|}{$\begin{array}{l}\text { Accumulated risk in } 25 \text { years for each group. } \\
\text { Score = sum of: } \\
\text { personal history of } M M=1 \text {; } \\
\text { family history of } M M=2 \text {. }\end{array}$}} \\
\hline & + & + & - & + & & & \\
\hline & + & + & + & + & & & \\
\hline D2 & + & $+1-$ & $+/-$ & $\begin{array}{l}>1 \text { family } \\
\text { member }\end{array}$ & & & \\
\hline \multicolumn{8}{|c|}{$\begin{array}{l}\text { AN: dyspalsticl nevus; CM: cutaneous melanoma } \\
\text { (+): One or more relatives with CM } \\
\text { A and C: sporadic AMS } \\
\text { D1 only one relative in the family had melanoma (may be the } \\
\text { patient) } \\
\text { D2 at least two relatives had melanoma (may include the } \\
\text { patient) } \\
\text { Relatives: grandparents, parents, uncles, sons }\end{array}$} \\
\hline
\end{tabular}

Figure 3 - Kraemer and Rigel Classifications. 
and/or family history of melanoma, giving one point to the personal history of melanoma and two points for family history of melanoma (Figure 3). The sum of the points gives rise to the following groups and their respective relative risks (RR) of developing melanoma: group 0: no points (RR: 2-92); group I: 1 point (RR: 8-127); group II: 2 points (RR: 33444); group III: 3 points (RR: 85-1269) (Figure 3). 3,15,30

Thus, the presence of dysplastic nevi and AMS can be considered as a spectrum of phenotypic expressions, which confers to the carriers different risks of developing melanoma. $^{3,21}$ The risk spectrum varies from individuals with sporadic dysplastic nevi, with no personal or family history of melanoma, to the opposite extreme with AMS individuals belonging to families in which two or more members had melanoma, forming the so-called familial atypical multiple-mole melanoma syndrome (FAMMM). $., 4,15,16,20,31$

Besides presenting an increased risk of developing cutaneous melanoma, AMS patients tend to present neoplasia in unusual sites (such as the scalp) at an earlier age than the non-carriers of the syndrome. ${ }^{1}$ There is also increased risk for multiple melanomas and non-cutaneous melanoma in those patients, such as ocular melanoma. ${ }^{8}$

Prospective studies show that the risk of melanoma in members of families affected by AMS and FAMMM is significant, with an estimated cumulative risk of $49 \%$ in individuals 10 to 50 years of age and $82 \%$ in individuals 72 years of age. $^{32}$

\section{Histopathology}

Although the histopathologic exam is considered to be the gold standard for the diagnosis of melanocytic tumors, there are limitations in the histologic distinction between early melanomas and dysplastic nevi. ${ }^{12}$ In several studies, the reproducibility in grading the atypia remains poor to moderate, due to a lack of uniform criteria among dermatopathologists. ${ }^{12,18}$

Based on the World Health Organization (WHO) and $\mathrm{NIH}$ consensus, the histopathologic diagnosis of dysplastic nevi (Figure 4) is based on the major criteria (mandatory)

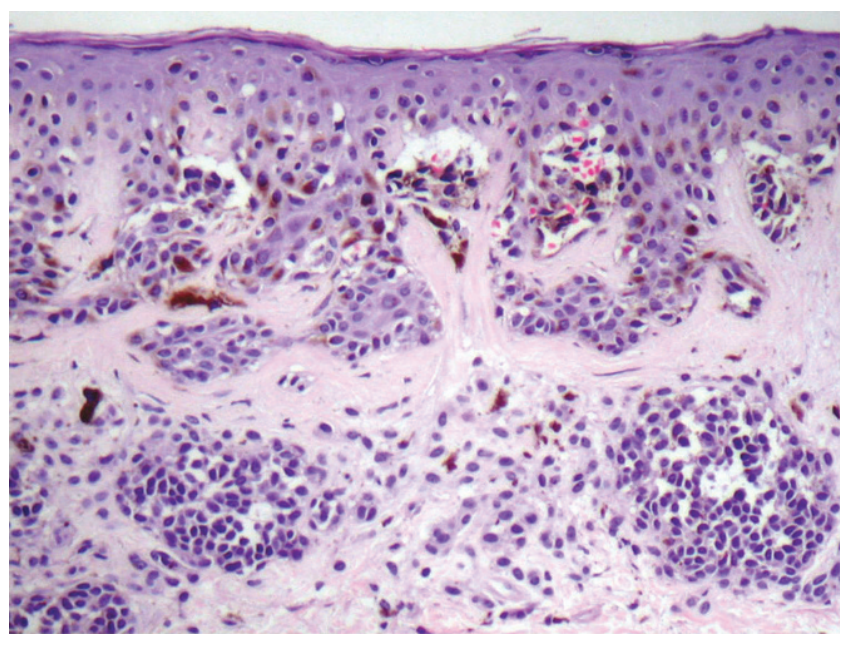

Figure 4 - Histopathologic exam of atypical nevus showing focal atypia of melanocytes, fusion of epithelial cones and concentric lamellar fibrosis. Optical microscopy image with high magnification (40X). and minor criteria (at least two must be present) ${ }^{23}$, detailed in Table 2.

\section{Diagnosis and Follow-Up}

The clinical distinction between benign and malignant pigmented lesions can be challenging in some cases. However, as demonstrated by several studies, the use of dermoscopy, an auxiliary noninvasive diagnostic method in the clinical dermatological examination, it is possible to increase the diagnostic accuracy of pigmented lesions, including melanomas. ${ }^{33}$ In a meta-analysis of 27 studies, Kittler et al. ${ }^{34}$ demonstrated a $49 \%$ improvement in diagnostic accuracy, with $6 \%$ and $19 \%$ increases in specificity and sensitivity, respectively. Moreover, in a randomized study to evaluate the procedure adopted for pigmented lesions using the dermatoscope, Carli et al. ${ }^{35}$ demonstrated a reduction in the number of patients referred for biopsy $(9.0 \%$ versus $15.6 \%)$. In recent decades, several diagnostic algorithms have been described in dermoscopy for the recognition of melanoma including the Pattern Analysis Method, the ABCD rule, the 7-Point Checklist, the $\mathrm{CASH}$ algorithm, the Menzies method and others. ${ }^{33}$ In a comparison of three algorithms (Pattern Analysis, ABCD Rule and the 7-Point Checklist), Annensi et al. ${ }^{36}$ demonstrated that the Pattern Analysis method provided the highest sensitivity, specificity and accuracy for the diagnosis of thin melanomas.

Although they do not solve all the diagnostic difficulties surrounding the atypical nevus, dermoscopic evaluation and especially monitoring greatly improve the management of these lesions of uncertain behavior. ${ }^{12}$

Both benign and indeterminate patterns can be identified in dysplastic nevi, using dermoscopy ${ }^{37}$ (Figure 5). The features most commonly found in dysplastic nevi, described by the Pattern Analysis are the following: atypical pigment network, areas of irregular and peripheral depigmentation, pigmentation with central heterogeneity and abrupt termination and brown globules of different shapes and sizes with irregular distribution. ${ }^{38,39}$ In dysplastic nevi, black dots in the periphery, pseudopods, branched streaks and bluewhitish veil are rarely found. These structures are more frequently found in cutaneous melanoma. ${ }^{38,39}$

The pigmented skin lesions with very atypical or nonspecific dermoscopic patterns should be excised for definitive diagnosis by pathology. ${ }^{40,41}$

Moreover, in patients with multiple nevi, including those with dysplastic nevi and AMS, who tend to have a large number of evolving lesions, dermoscopy alone is not always sufficient to distinguish between benign lesions or new individually suspicious ones. ${ }^{8,42}$ Thus, the monitoring of nevi in at-risk patients by total body mapping and digital dermoscopy is crucial for both early identification of

Table 2 - Dyspalstic Nevus - Histopathological Criteria (NIH).

\footnotetext{
Major Criteria (mandatory)

Lentiginous or contiguous melanocytic hyperplasia

Focal melanocytic atypia

Minor Criteria (at least 2)

'Shoulder phenomenon'

Fusion of epithelial cones

Subepidermal concentric lamellar fibrosis

Superficial perivascular lymphocytic inflammatory infiltrate
} 

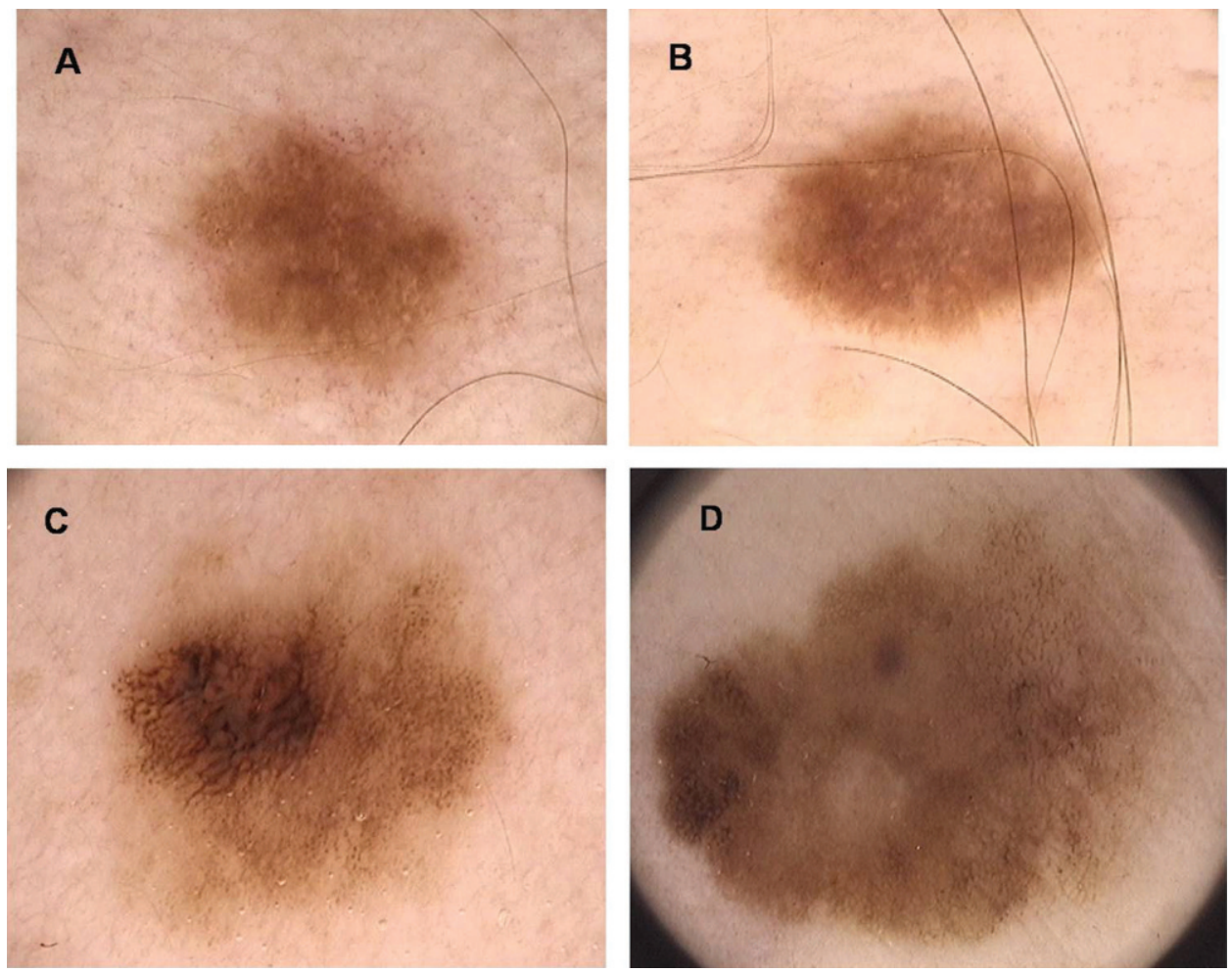

Figure 5 - Digital dermoscopy $(20 \mathrm{X})$ of melanocytic lesions that have similar dermatoscopic appearance $(A \sim B ; C \sim D): A)$ compound melanocytic nevus; B) dysplastic nevus; C) dysplastic junctional nevus with severe atypia, D) thin melanoma.

malignant lesions and the minimization of unnecessary biopsies of benign lesions. ${ }^{43,44}$

Total body mapping and digital dermoscopy allow for storage of macroscopic and dermoscopic images for comparison over time. Follow-up procedures using this technique can be accomplished in short and long term. The long-term follow-up is performed at intervals of 9 to 12 months and is more suitable for risk patients with multiple nevi, including those with AMS ${ }^{45}$ In this type of follow-up, changes that indicate lesion excision include the following: growth, change in shape, regression, changes in color and appearance of dermoscopic structures known to be associated with melanomas. ${ }^{34}$ In short term follow-up, the revaluation of the lesions must occur within 3 months from the first visit and is indicated for suspicious melanocytic lesions that have no dermoscopic features of melanoma. These include clinically moderate atypical lesions and less atypical ones that present a change history. ${ }^{45}$ The lesion should be excised when it presents any kind of morphological change except alterations in the number of milia cysts or global aspect of pigmentation. ${ }^{46}$

\section{Follow-up recommendations for AMS patients}

The importance of early identification and treatment of melanoma is well established, as evidenced by the differences between the survival curves of patients at different stages as determined by the American Joint Committee on Cancer (AJCC) that show a 5-year survival rate around $95 \%$ for patients in Stage I and 15\% for patients in Stage IV. ${ }^{6,47}$ Therefore, follow-up strategies for high risk populations such as those with AMS are justified by maximizing opportunities for detecting melanoma in its early stages. ${ }^{3}$
As the majority of melanomas arise de novo and only about $20-30 \%$ arise in a pre-existing nevus, atypical melanocytic nevi are considered important risk markers. ${ }^{26}$ Thus, prophylactic excision of all clinically dysplastic nevi in a subject with multiple nevi is unfounded and often not feasible. ${ }^{18}$ This approach could give the patient a false sense of security since their increased risk of melanoma persists even with the removal of all melanocytic lesions.

A periodic dermatological examination is generally recommended for patients with dysplastic nevi or AMS, ranging from an examination every 3-12 months, depending on a patient's position within the risk spectrum described above. ${ }^{3}$ Thus, some authors propose that patients of Rigel's group 0 be examined annually, while those with higher risk (Rigel I, II or III) should be evaluated by a dermatologist every 3 to 6 months. ${ }^{3}$ According to Tucker et al. ${ }^{32}$, the risk of melanoma for patients with AMS in families predisposed to melanoma begins to increase at around 10 years of age and so it is recommended that monitoring begin at puberty. ${ }^{3}$

Physical examination of the entire integument is essential because most melanomas occur on covered areas and previous studies have demonstrated that the detection of melanoma was 6 times more frequent in patients who undressed completely. ${ }^{3,48}$

As mentioned above, dermoscopy increases the diagnostic accuracy of melanocytic neoplasias, and its implementation is recommended during dermatologic consultation. ${ }^{48,49,50,51}$

However, even with the aid of a dermatoscope, identification of new lesions and significant changes in nevi in individuals with multiple pigmented lesions and AMS can be challenging, making total body mapping and digital dermoscopy of great benefit to the diagnostic process. ${ }^{43,44}$ In 
the protocol followed by the Dermoscopy Clinic of the Skin Oncology Department of Hospital AC Camargo, risk patients are reevaluated 3 months after the first visit, with a third evaluation 6 months after the last one, followed by annual tracking. In a survey including risk patients who underwent their first examination between March 2003 and November 2007, a total of 255 patients were observed, 53 of whom presented with AMS. 14,307 lesions were followedup and 355 showed changes over time (2.5\%). Of these, 10 lesions were diagnosed as cutaneous melanoma, all presenting a thickness under $1 \mathrm{~mm}$, including 5 in situ melanomas. The main risk factors associated with malignant transformation were personal history of melanoma (OR 11.3) and AMS (OR 5.1) (unpublished data).

Any suspicious lesion and/or significant change should be considered for biopsy, preferably by excision with conservative surgical margins $(2 \mathrm{~mm})$ providing adequate samples for histopathological evaluation., ${ }^{3,8}$ Non-surgical alternatives such as topical 5-fluorouracil, systemic isotretinoin, topical tretinoin with or without hydrocortisone, topical imiquimod and laser ablation are not effective or safe for the removal of suspicious lesions and are not recommended. 8,52 .

Education of patients with dysplastic nevi or AMS in self-examination of the skin is relatively simple and inexpensive, and some studies have suggested increased detection of thin melanomas or greater survival in patients who performed self-examination in comparison with those who did not. ${ }^{18}$ Slade et al. $^{3}$ recommend self-examination of the skin every 2 to 3 months. Given the increased prevalence of uveal melanoma in patients with AMS, some authors recommend routine annual assessment by an ophthalmologist. $^{53,54}$

Ultraviolet light is known to be "nevogenic" and appears to contribute to the emergence of dysplastic nevi. 3,55 Furthermore, UV radiation acts as an initiator and promoter in the process of malignant transformation of melanocytes. ${ }^{3}$ It was demonstrated that patients with hereditary AMS have reduced abilities to repair DNA damage induced by ultraviolet light. ${ }^{56,57}$ Therefore, the patient should avoid exposure to sunlight or artificial ultraviolet light (such as tanning beds) and use physical protection in the prevention of sunburn. ${ }^{3,18}$ Although it has not been documented that the use of sunscreen prevents the emergence of dysplastic nevi or decreases the risk of developing melanoma, it has been shown that a sunscreen with a Sun Protection Factor of at least 15 reduces the incidence of actinic keratoses and decreases the development of melanocytic nevi. ${ }^{3,18}$ The patient must be advised not to use sunscreen in order to prolong exposure, which may in fact increase the risk of developing melanoma., 3

Prospective studies show that the risk of melanoma in families of patients with AMS is considerable. ${ }^{32}$ In addition, many patients initially considered as having sporadic AMS actually belong to families with AMS. $^{3}$ Therefore, it is recommended that first-degree relatives of AMS patients be examined by a dermatologist for the presence of dysplastic nevi, AMS or melanoma.

Because carriers of AMS and FAMMM evidence an association between melanoma and other internal malignancies (pancreatic neoplasia, central nervous system tumors, breast cancer) ${ }^{3}$, evaluation by a specialist is therefore recommended in the case of suspected symptoms in these patients.
Currently, there is no scientific basis for performing genetic testing in AMS patients except in research protocols. $^{18,58,59}$

\section{CONCLUSION}

AMS demonstrably increases the risk of developing melanoma, a malignant neoplasm for which incidence have increased significantly in recent decades and for which early diagnosis is of great importance in the prognosis of the disease. $^{4,59}$ The identification of patients with AMS, the main clinical risk factor, allows them to be included in short and long term monitoring programs, aimed at early detection of suspicious lesions and the consequent reduction in mortality associated with advanced melanoma. ${ }^{42}$ In addition, a prevention program could contribute to increased awareness and changes in risk behavior, minimizing the environmental risk not only for patients but also for their families.

\section{REFERENCES}

1. Newton JA, Bataille V, Griffiths K, Squire JM, Sasieni P, Cuzick J, et al. How common is the atypical mole syndrome phenotype in apparently sporadic melanoma? J Am Acad Dermatol. 1993;29: 989-96, doi: 10.1016/ 0190-9622(93)70279-3.

2. Gandini S, Sera F, Cattaruzza MS, Pasquini P, Abeni D, Boyle P, et al. Meta-analysis of risk factors for cutaneous melanoma: I. Common and atypical naevi. Eur J Cancer. 2005;41:28-44.

3. Slade I, Marghoob AA, Salopek TG, Rigel DS, Kopf AW, Bart RS Atypical mole syndrome: Risk factor for cutaneous malignant melanoma and implications for management. J Am Acad Dermatol. 1995;32:479-94, doi: 10.1016/0190-9622(95)90073-X.

4. Miller AJ, Mihm MC Jr. Melanoma. N Engl J Med. 2006;355:51-65.

5. Thompson JF, Scolyer RA, Kefford RF. Cutaneous Melanoma. Lancet. 2005;365:687-701.

6. Balch CM, Gershenwald JE, Soong SJ, Thompson JF, Atkins MB, Byrd DR, et al. Final Version of 2009 AJCC Melanoma Staging and Classification. J Clin Oncol. 2009;27:6199-206, doi: 10.1200/JCO.2009.23. 4799.

7. Tsao H, Atkins MB, Sober AJ. Management of Cutaneous Melanoma. N Engl J Med. 2004;351:998-1012.

8. Friedman RJ, Farber MJ, Warycha MA. The "dysplastic" nevus. Clin Dermatol. 2009;27:103-15, doi: 10.1016/j.clindermatol.2008.09.008.

9. Nelson AA, Tsao H. Melanoma and genetics. Clin Dermatol. 2009; 27:4652, doi: 10.1016/j.clindermatol.2008.09.005.

10. Norris W. Case of Fungoid Disease. Edinburgh Medical and Surgical Journal. 1820;16:562-65.

11. Clark WH Jr, Reimer RR, Greene M, Ainsworth AM, Mastrangelo MJ. Origin of familial malignant melanomas from heritable melanocytic lesions. 'The B-K mole syndome'. Arch Dermatol. 1978;114:732-8, doi: 10 1001/archderm.114.5.732.

12. Roesch A, Burgdorf W, Stolz W, Landthaler M, Vogt T. Dermatoscopy of "dysplastic nevi" : A beacon in diagnostic darkness. Eur J Dermatol. 2006;16:479-93.

13. Elder DE. The dysplastic nevus. Pathology. 1985;17:291-7, doi: 10.3109/ 00313028509063770.

14. Clark WH Jr, Elder DE, Guerry D 4th, Epstein MN, Greene MH, Van Horn M. A study of tumor progression: the precursor lesions of superficial spreading and nodular melanoma. Hum Pathol. 1984; 15:1147-65, doi: 10.1016/S0046-8177(84)80310-X.

15. Rigel DS, Rivers JK, Friedman RJ, Kopf AW. Risk gradient for malignant melanoma in individuals with dysplastic naevi. Lancet. 1988;1:352-3, doi: 10.1016/S0140-6736(88)91139-7.

16. Kraemer KH, Greene MH, Tarone R, Elder DE, Clark WH Jr, Guerry D $4^{\text {th }}$. Dysplastic naevi and cutaneous melanoma risk. Lancet. 1983; 2: 10767, doi: 10.1016/S0140-6736(83)91055-3.

17. Carey WP, Thompson CJ, Synnestvedt M, Guerry D $4^{\text {th }}$, Halpern A, Schultz D, et al. Dysplastic Nevi as a Melanoma Risk Factor in Patients with Familial Melanona. Cancer. 1994; 74: 3118-25, doi: 10.1002/10970142(19941215)74:12<3118::AID-CNCR2820741210>3.0.CO;2-7.

18. Naeyaert JM, Brochez L. Dysplastic Nevi. N Engl J Med. 2003; 349:223340

19. Berwick M, Erdel E, Hay Jennifer. Melanoma Epidemiology and Public Health. Dermatol Clin. 2009;27:205-14, doi: 10.1016/j.det.2008.12.002

20. de Snoo FA, Hottenga JJ, Gillanders EM, Sandkuijl LA, Jones MP Bergman W, et al. Genome-wide linkage scan for atypical nevi in p16Leiden melanoma families. Eur J Hum Genet. 2008;16:1135-4. 
21. Kraemer $\mathrm{KH}$, Greene MH. Dysplastic nevus syndrome: familial and sporadic precursor of cutaneous melanoma. Dermatol Clin. 1985;3:22537, doi: 10.1016/0738-081X(85)90096-3.

22. Celebi JT, Ward KM, Wanner M, Polsky D, Kopf AW. Evaluation of germline CDKN2A, ARF, CDK4, PTEN, and BRAF alterations in atypical mole syndrome. Clin Exp Dermatol. 2005;30:68-70, doi: 10.1111/j.13652230.2004.01656.x

23. Landman G. Atypical (dysplastic) cell nevus: histopathology and historical aspects. Acta oncol. Bras. 2003;23:514-20.

24. Goldstein AM, Martinez M, Tucker MA, Demenais F. Gene-covariate interaction between dysplastic nevi and the CDKN2A gene in American melanoma-prone families. Cancer Epidemiol Biomarkers Prev. 2000:9:889-94.

25. Chaudru V, Laud K, Avril MF et al. Melanocortin-1 receptor (MC1R) gene variants and dysplastic nevi modify penetrance of CDKN2A mutations in French melanoma-prone pedigrees. Cancer Epidemiol Biomarkers Prev. 2005;14:2384-90, doi: 10.1158/1055-9965.EPI-04-0777.

26. Bevona C, Goggins W, Quinn T, Fullerton J, Tsao H. Cutaneous melanomas associated with nevi. Arch Dermatol. 2003;139:1620-4, doi: 10.1001/archderm.139.12.1620.

27. Halpern AC, Guerry D 4th, Elder DE, Trock B, Synnestvedt M, Humphreys T, . Natural history of dysplastic nevi. J Am Acad Dermatol. 1993;29:51-7, doi: 10.1016/0190-9622(93)70151-I.

28. Kopf AW, Friedman RJ, Rigel DS. Atypical mole syndrome. J Am Acad Dermatol. 1990;22:117-8, doi: 10.1016/S0190-9622(08)80006-0.

29. NIH Consensus conference. Diagnosis and treatment of early melanoma. JAMA. 1992;268:1314-9, doi: 10.1001/jama.268.10.1314.

30. Rigel DS, Rivers JK, Kopf AW, Friedman RJ, Vinokur AF, Heilman ER, et al. Dysplastic nevi: markers for increased risk for melanoma. Cancer. 1989;63:386-9, doi: 10.1002/1097-0142(19890115)63:2<386::AIDCNCR2820630231>3.0.CO;2-6.

31. Lynch HT, Frichot BC III, Lynch JF. Familial atypical multiple molemelanoma syndrome. J Med Genet. 1978;.15:..352-6, doi: 10.1136/jmg.15. 5.352.

32. Tucker MA, Fraser MC, Goldstein AM, Elder DE, Guerry D 4th, Organic $\mathrm{SM}$, et al. The risk of melanoma and other cancers in melanoma-prone families. J Invest Dermatol. 1993; 100: 350-5, doi: 10.1038/jid.1993.62.

33. Terushkin V, Halpern AC. Melanoma Early Detection. Hematol Oncol Clin North Am. 2009;23:481-500, doi: 10.1016/j.hoc.2009.03.001.

34. Kittler H, Pehamberger H, Wolff K, Binder M. Follow-up of melanocytic skin lesions with digital epiluminescence microscopy: patterns of modifications observed in early melanoma, atypical nevi, and common nevi. J Am Acad Dermatol. 2000;43:467-76, doi: 10.1067/mjd.2000.107504.

35. Carli P, de Giorgi V, Chiarugi A et al. Addition of dermoscopy to conventional naked-eye examination in melanoma screening: a randomized study. J Am Acad Dermatol. 2004;50:683-9, doi: 10.1016/j.jaad. 2003.09.009.

36. Annessi G, Bono R, Sampogna F, Faraggiana T, Abeni D. Sensitivity, specificity, and diagnostic accuracy of three dermoscopic algorithmic methods in the diagnosis ofdoubtful melanocytic lesions: the importance of light brown structureless areas in differentiating atypical melanocytic nevi from thim melanomas. J Am Acad Dermatol. 2007;56:759-67, doi: 10. 1016/j.jaad.2007.01.014.

37. Malvehy J, Puig S, Braun R, Marghood A, Kopf A. Lesiones Melanocíticas In: Malvehy J, Puig S, Braun R, Marghood A, Kopf A, eds. Manual de Dermatoscopía. Barcelona: BCN Art Directe S.L.; 2006. p45-54.

38. Rezze GG, Soares de Sá BC, Neves RI. Dermatoscopia: o método de análise de padrões. An Bras Dermatol. 2006:81:261-8, doi: 10.1590/S036505962006000300009.

39. Soares de Sá BC, Rezze GG. Dermatoscopia dos Nevos Atípicos. In: Rezze GG, Soares de Sá BC, Neves RI, eds. Atlas de Dermatoscopia Aplicada, 1st. ed. São Paulo, SP: Lemar-Martinari; 2009. p103-7.

40. Nathansohn N, Orenstein A, Trau H, Liran A, Schachter J. Pigmented lesions clinic for early detection of melanoma: preliminary results. Isr Med Assoc J. 2007;9:708-12.
41. Bowling J, Argenziano G, Azenha A, Bandic J, Bergman R, Blum A, et al. Dermoscopy key points: recommendations from the international dermoscopy society. Dermatology. 2007;214:3-5, doi: 10.1159/000096904

42. Haenssle HA, Vente C, Bertsch HP, Rupprecht R, Abuzahra F, Junghans $\mathrm{V}$, et al. Results of a surveillance programme for patients at high risk of malignant melanoma using digital and conventional dermoscopy. Eur J Cancer Prev. 2004;13:133-8, doi: 10.1097/00008469-20040400000007.

43. Lucas CR, Sanders LL, Murray JC, Myers SA, Hall RP, Grichnik JM. Early melanoma detection:nonuniform dermoscopic features ad growth. J Am Acad Dermatol. 2003;48:663-71, doi: 10.1067/mjd.2003.283.

44. Banky JP, Kelly JW, English DR, Yetman JM, Dowling JP. Incidence of new and changed nevi and melanomas detected using baseline images and dermoscopy in patients with high risk for melanoma. Arch Dermatol. 2005;141:998-1006, doi: 10.1001/archderm.141.8.998.

45. Menzies SW. Cutaneous melanoma: making a clinical diagnosis, present and future. Dermatol Ther. 2006;19:32-9, doi: 10.1111/j.1529-8019.2005. 00054.x.

46. Menzies SW, Gutenev A, Avramidis M, Batrac A, McCarthy WH. Shortterm digital surface microscopic monitoring of atypical or changing melanocytic lesions. Arch Dermatol. 2001;137:1583-9.

47. Balch CM, Buzaid AC, Soong SJ, Atkins MB, Cascinelli N, Coit DG, et al. Final Version of the American Joint Committee on Cancer Staging System for Cutaneous Melanoma. J Clin Oncol. 2001;19:3635-48.

48. Rigel DS, Friedman RJ, Kopf AW, Weltman R, Prioleau PG, Safai B, et al. Importance of complete cutaneous examination for the detection of malignant melanoma. J Am Acad Dermatol. 1986;14: 857-60, doi: 10. 1016/S0190-9622(86)70100-X

49. Pehamberger H, Steiner A, Wolff K. In vivo epiluminescence microscopy of pigmented skin lesions: I. pattern analysis of pigmented skin lesions. J Am Acad Dermatol. 1987;17:571-83, doi: 10.1016/S0190-9622(87)70239-4

50. Steiner A, Pehamberger H, Wolff K. In vivo epiluminescence microscopy of pigmented skin lesions: II. Diagnosis of small pigmented skin lesions and early detection of malignant melanoma. J Am Acad Dermatol 1987;17:584-91.

51. D Aurea Machado EDB. Histório e Fundamentos da Dermatoscopia. In: Rezze GG, Soares de Sá BC, Neves RI, eds. Atlas de Dermatoscopia Aplicada, 1st. ed. São Paulo, SP: Lemar-Martinari; 2009. p17-21.

52. Stratigos AJ, Dover JS, Arndt KA. Laser treatment of pigmented lesions 2000: how far have we gone? Arch Dermatol. 2000;136: 915-21, doi: 10. 1001/archderm.136.7.915.

53. Rodriguez-Sains RS. Ocular findings in patients with dysplastic nevus syndrome. Ophthalmology. 1986;93:661-5.

54. Vink J, Crijns MB, Mooy CM et al. Ocular melanoma in families with dysplastic nevus syndrome. J Am Acad Dermatol. 1990;23: 858-62, doi: 10.1016/0190-9622(90)70304-Z.

55. Elwood JM, Gallagher RP, Hill GB, Spinelli JJ, Pearson JC, Threlfall W. Pigmentation and skin reaction to sun as risk factors for cutaneous melanoma: Western Canada Melanoma Study. Br Med J. 1984;288:99-102, doi: $10.1136 /$ bmj.288.6411.99.

56. Noz KC, Bauwens M, van Buul PP, Vrolijk H, Schothorst AA, Pavel S, et al. Comet assay demonstrates a higher ultraviolet B sensitivity to DNA damage in dysplastic nevus cells than in common melanocytic nevus cells and foreskin melanocytes. J Invest Dermatol. 1996;106:1198-202, doi: 10.1111/1523-1747.ep12347994.

57. Perera MI, Um KI, Greene MH, Waters HL, Bredberg A, Kraemer KH. Hereditary dysplastic nevus syndrome: lymphoid cell ultraviolet hypermutability in association with increased melanoma susceptibility. Cancer Res. 1986;46:1005-9.

58. Niendorf KB, Tsao H. Cutaneous melanoma: Family screening and genetic testing. Dermatol Ther. 2006; 19: 1-8, doi: 10.1111/j.1529-8019. 2005.00050.x.

59. Pho L, Grossman D, Leachman AS. Melanoma genetics: a review of genetic factor and clinical phenotypes in familial melanoma. Curr Opin Oncol. 2006;18:173-9, doi: 10.1097/01.cco.0000208791.22442.09. 
This article has received corrections asked by theeditor on 2011 in agreement with the ERRATUM published in Volume 66 Number 7. (http://www.scielo.br/pdf/clin/v66n7/v66n7a32.pdf) 